\title{
Application of GIS-based multi-criteria analysis for site selection of aquifer recharge with reclaimed water
}

\author{
Francisco Pedrero $^{\mathrm{a}, 1}$, António Albuquerque ${ }^{\mathrm{b}, *}$, Helena Marecos do Monte ${ }^{\mathrm{c}, 3}$, Victor Cavaleiro $^{\mathrm{b}, 2}$, \\ Juan José Alarcón ${ }^{\text {a, } 1}$ \\ a Irrigation Department, Centro de Edafología y Biología Aplicada del Segura (CEBAS-CSIC), Campus Universitario de Espinardo, 30100 Murcia, Spain \\ ${ }^{\mathrm{b}}$ Department of Civil Engineering and Architecture, University of Beira Interior, Edificio 2 das Engenharias, Calcada Fonte do Lameiro, 6201-001 Covilha, Portugal \\ ${ }^{\mathrm{c}}$ Department of Civil Engineering, High Institute of Engineering of Lisbon (ISEL), R. Conselheiro Emídio Navarro, 1, 1950-062 Lisbon, Portugal
}

\section{A R T I C L E I N F O}

\section{Article history:}

Received 8 March 2011

Received in revised form 8 August 2011

Accepted 8 August 2011

\section{Keywords:}

Aquifer recharge

GIS

Multi-criteria analysis

Reclaimed water

Reuse

Site selection

\begin{abstract}
A B S T R A C T
Reclaimed water from small wastewater treatment facilities in the rural areas of the Beira Interior region (Portugal) may constitute an alternative water source for aquifer recharge. A 21-month monitoring period in a constructed wetland treatment system has shown that $21,500 \mathrm{~m}^{3}$ year ${ }^{-1}$ of treated wastewater (reclaimed water) could be used for aquifer recharge. A GIS-based multi-criteria analysis was performed, combining ten thematic maps and economic, environmental and technical criteria, in order to produce a suitability map for the location of sites for reclaimed water infiltration. The areas chosen for aquifer recharge with infiltration basins are mainly composed of anthrosol with more than $1 \mathrm{~m}$ deep and fine sand texture, which allows an average infiltration velocity of up to $1 \mathrm{~m} \mathrm{~d}^{-1}$. These characteristics will provide a final polishing treatment of the reclaimed water after infiltration (soil aquifer treatment (SAT)), suitable for the removal of the residual load (trace organics, nutrients, heavy metals and pathogens). The risk of groundwater contamination is low since the water table in the anthrosol areas ranges from $10 \mathrm{~m}$ to $50 \mathrm{~m}$. On the other hand, these depths allow a guaranteed unsaturated area suitable for SAT. An area of 13,944 ha was selected for study, but only 1607 ha are suitable for reclaimed water infiltration. Approximately $1280 \mathrm{~m}^{2}$ were considered enough to set up 4 infiltration basins to work in flooding and drying cycles.
\end{abstract}

(c) 2011 Elsevier B.V. All rights reserved.

\section{Introduction}

In the context of the implementation of the 2000/60/EC Directive (water framework Directive) and the recommendations of the World Water Assessment Programme (UNESCO, 2009), sustainable management of water requires an approach that, on one hand, allows controlling of aquatic pollution and protecting of water resources, which can be achieved through the adequate provision of wastewater treatment facilities. On the other hand, it is essential to ensure the availability of this resource, in terms of quantity and quality, in order to satisfy uses such as public supply and agricultural irrigation. Approximately $40 \%$ of the total surface area of Portugal is utilised as agricultural land (3.68 million ha), $86.6 \%$ of which has a deficit in organic matter, nutrients and minerals, whilst

\footnotetext{
* Corresponding author. Tel.: +351 275329981; fax: +351275329969

E-mail addresses: fpedrero@cebas.csic.es (F. Pedrero), ajca@ubi.pt, ajcalb@netvisao.pt (A. Albuquerque),hmarecos@dec.isel.ipl.pt (H. Marecos do Monte).

1 Tel.: +34 968396303; fax: +34968396213.

2 Tel.: +351275329981; fax: +351275329969.

3 Tel.: +351218317002; fax: +351218317021.
}

$75 \%$ of the territory is covered by agro-forestry (Marecos do Monte and Albuquerque, 2010b). According to Marecos do Monte (2007), $58 \%$ of the country mainland suffers a water deficit that may bring serious consequences to the economy.

Over the last decade, the country has invested strongly in the construction and rehabilitation of low cost wastewater treatment plants (WWTP) for small populations (less than 2000 inhabitants, especially in the rural areas, which constitute $85 \%$ of the country), in the context of the 1991/271/EC Directive (urban wastewater treatment). According to UNESCO (2009), this kind of solution and the selective reuse of reclaimed water will constitute one of the great challenges for integrated water management in rural areas over the next two decades. The rural areas of the Beira Interior region have several golf course projects, SPA resorts with therapeutic treatment and important agricultural activities that represent an economic gain for the region and require a considerable availability of water. However, in recent years the region experienced a serious water shortage period that may undermine activities.

The nearly four hundred small WWTP operating in that region could contribute to satisfying the demands of those activities through the reuse of their treated effluents. Most of the small WWTP are constructed wetlands (CW), which are considered a low- 
Table 1

Mean precipitation $(P)$, potential evapotranspiration (ETp) and deficit in the studied area for the period 1965-1994 (Cavaleiro, 2002)

\begin{tabular}{|c|c|c|c|c|c|c|c|c|c|c|c|c|c|}
\hline & Jan & Feb & Mar & Apr & May & Jun & Jul & Aug & Sep & Oct & Nov & Dec & Total \\
\hline$P(\mathrm{~mm})$ & 101 & 104 & 47.1 & 70.5 & 69.2 & 37.9 & 12.5 & 10.6 & 35.9 & 99.1 & 105.4 & 90.9 & 784.1 \\
\hline $\operatorname{ETp}(\mathrm{mm})$ & 10.5 & 15.1 & 28.9 & 45.5 & 67.1 & 105.6 & 127.2 & 119.7 & 90 & 52.8 & 25.2 & 11.7 & 699.8 \\
\hline Deficit (mm) & 90.4 & 88.8 & 18.1 & 24.9 & 2.0 & -67.7 & -114.7 & -109.1 & -54.1 & 46.2 & 80.1 & 79.1 & 84.2 \\
\hline
\end{tabular}

The shaded areas mean that Evapotranspiration was higher than Precipitation.

cost technology (Vymazal and Kropfelova, 2008) for wastewater treatment. Besides providing secondary treatment, CW may also be used as polishing treatment, which is especially useful when the receiving streams are considered sensitive or for reuse practices (Ghermandi et al., 2005; Marecos do Monte and Albuquerque, 2010a).

The use of reclaimed water is already a practice in Portugal, mainly for agricultural and public spaces irrigation. According to Angelakis et al. (1999), the estimated treated wastewater discharged into water streams would be sufficient to supply $10 \%$ of water needs for irrigation in dry years without seasonal storage. Approximately $580 \mathrm{Mm}^{3}$ year $^{-1}$ could be used for different purposes in rural areas of Portugal. Roughly, between 35,000 and
100,000 ha could be irrigated with recycled water, depending on storage capacity (Angelakis et al., 2003).

The main reuse opportunities in the Beira Interior region would be for irrigation of agricultural activities, golf courses, landscape and aquifer recharge. The selection of reuse options should be made based on quantity, variability of the quality over time, reuse guidelines and regulations, climate changes, technical requirements for WWTP upgrade and reuse projects cost-effectiveness.

The increase of water demand in that region, particularly in the arid and semi-arid areas, reveals the significance of the extended groundwater reservoirs formed by aquifers as invaluable water supply sources and water storage formations. Many aquifers of the region are overexploited due to the increase of water demand for agricultural and landscape irrigation and SPA activities.

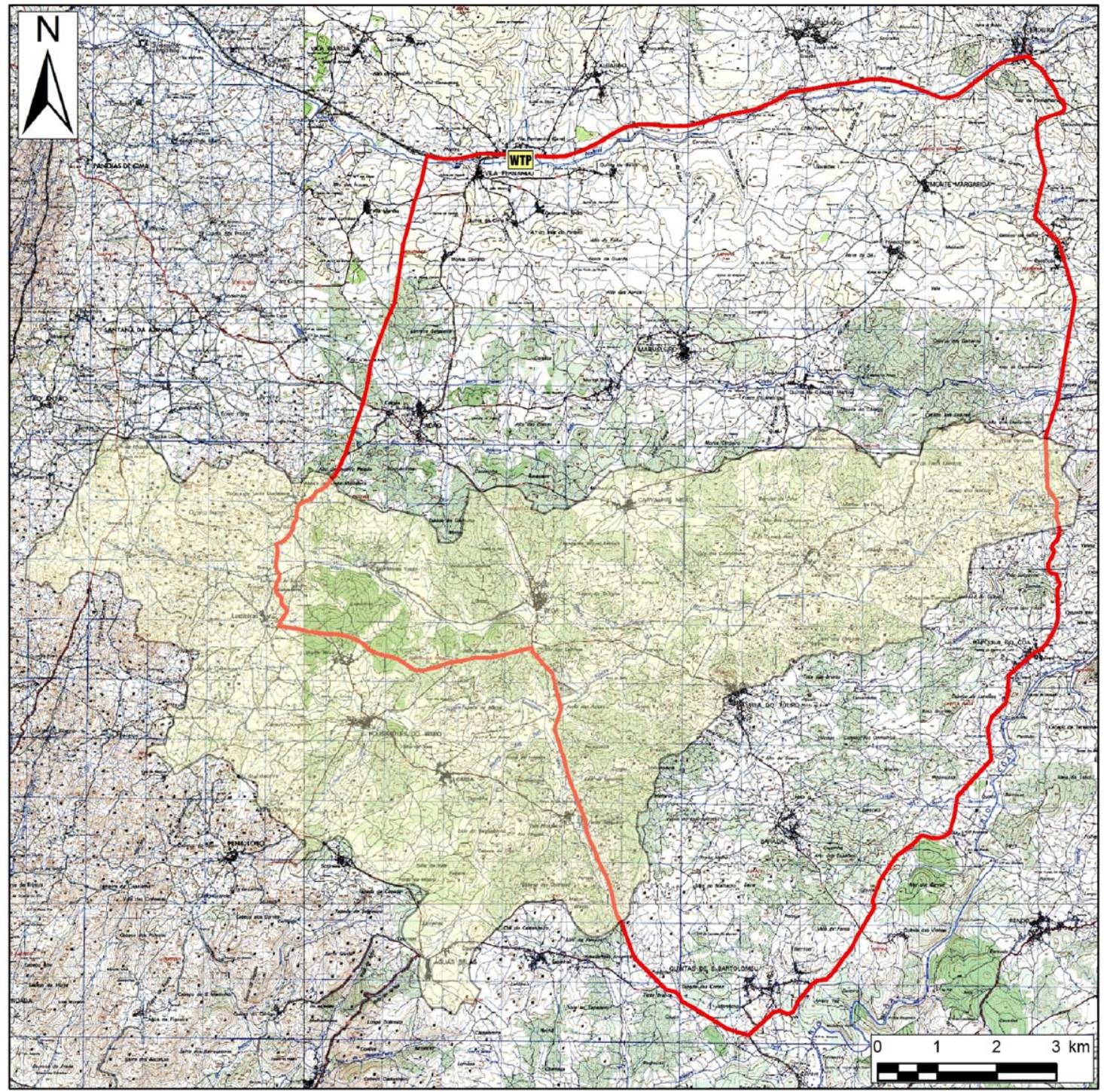

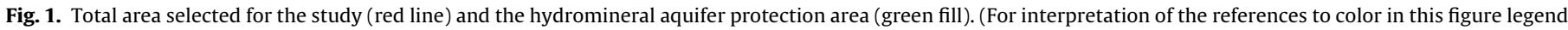
the reader is referred to the web version of the article.) 
Therefore, to overcome these problems, as suggested by Bouwer (2002), aquifer artificial recharge with reclaimed water, either by infiltration or by direct injection, would be an advantageous option. Groundwater recharge systems are technical, economical, and environmental sustainable solutions (Bouwer, 1999). Artificial recharge of groundwater also allows additional polishing of the reclaimed water through SAT or geopurification as the water moves through soils and aquifers (Asano et al., 2007). Experiences in Israel have shown that submitting secondary treated effluents to a SAT system in dune sand aquifers can result in the production of nearly potable water (Kanarek and Michail, 1996).

Ensuring that the use of reclaimed water for aquifer recharge does not result in adverse health effects requires a systematic science-based approach designed around critical control points. Trace compounds and pathogens are of particular concern when groundwater recharge involves domestic wastewater (Tsuchihashi et al., 2002).

Designing a project for reclaimed water infiltration in soil for aquifer recharge requires the collection, processing and analysis of complex information (e.g. land use, soil and aquifer characteristics, environmental and legal restrictions, characteristics of the reclaimed water and road accesses) and tools for multi-criteria analysis and site selection for the location of infiltration basins. Geographic Information Systems (GIS) allows the georeferencing, organization, processing and analysis of such complex information. GIS has been used in environmental sciences for creating suitability maps for pulp mill sludge application in soils (Ribeiro et al., 2010) and location of urban non-point pollution (Mitchell, 2005) and for site location of wastewater treatment facilities (Gemitzia et al., 2007)

This work aims to identify potential sites for reclaimed water (secondary treated wastewater) infiltration for groundwater recharge in the northwestern part of the Beira Interior region, using a GIS-based multi-criteria analysis. A local CW system was monitored during 21 months to assess the available quantity and quality of the reclaimed water.

\section{Materials and methods}

\subsection{Characterization of the study area}

This step included the selection of a study area taking into account the location of the SPA of Cró and its protected area and the source of reclaimed water (the WWTP of Vila Fernando, Guarda, Portugal). The following digital information was used:

- Extract of Portuguese Military Maps No. 192, 193, 194, 203, 204, $214,215,225$ and 226 (1/25,000 scale);

- Map of the protected area of the SPA of Cró (1/25,000 scale);

- Altimetry data (1/25,000 scale);

- Orthophotomaps (photogrammetric flights of 2002, 2003 and 2004; $1 / 5000$ scale).

The area is located in the northwestern part of the Beira Interior region (Vila Fernando parish) with altitudes ranging from $680 \mathrm{~m}$ to $820 \mathrm{~m}$ and is influenced by the moderate Mediterranean climate, with an average annual precipitation of $780 \mathrm{~mm}$, annual average temperature of $14.5^{\circ} \mathrm{C}$ and average evapotranspiration (ETp) of around $700 \mathrm{~mm}$. Therefore, a water deficit is expected during the period from June to September (Table 1 ).

Geologically, there are primitive soil formations, mainly granitic, with tertiary and quaternary revegetation. The predominant lithology is granitic with thick and medium grain. The hydrogeological area belongs to the hydrographic catchment of river Côa with a total area of 8017 ha (Cavaleiro, 2002). The main
Table 2

Characteristics of the wastewater in the CW of Vila Fernando (2008-2009).

\begin{tabular}{|c|c|c|}
\hline Parameters & Influent ${ }^{\mathrm{a}}$ & $\begin{array}{l}\text { Effluent (reclaimed } \\
\text { water) }^{\mathrm{a}}\end{array}$ \\
\hline Flow rate $\left(\mathrm{m}^{3} \mathrm{~d}^{-1}\right)$ & $58.9 \pm 26.0$ & - \\
\hline Temperature $\left({ }^{\circ} \mathrm{C}\right)$ & $15.6-3.8$ & $15.3-3.9$ \\
\hline $\mathrm{pH}$ & $6.2-7.3$ & $6.3-7.7$ \\
\hline $\mathrm{EC}\left(\mathrm{dS} \mathrm{m}^{-1}\right)$ & $0.22 \pm 0.02$ & $0.22 \pm 0.02$ \\
\hline $\mathrm{BOD}_{5}\left(\mathrm{mg} \mathrm{L}^{-1}\right)$ & $105.7 \pm 32.1$ & $27.4 \pm 7.2$ \\
\hline $\operatorname{COD}\left(\mathrm{mg} \mathrm{L}^{-1}\right)$ & $265.2 \pm 79.8$ & $83.9 \pm 13.0$ \\
\hline $\mathrm{TSS}\left(\mathrm{mg} \mathrm{L}^{-1}\right)$ & $64.0 \pm 19.2$ & $27.1 \pm 18.3$ \\
\hline $\mathrm{NH}_{4}-\mathrm{N}\left(\mathrm{mg} \mathrm{L}^{-1}\right)$ & $60.3 \pm 5.8$ & $54.4 \pm 7.4$ \\
\hline $\mathrm{NO}_{3}-\mathrm{N}\left(\mathrm{mg} \mathrm{L}^{-1}\right)$ & $1.7 \pm 1.5$ & $0.8 \pm 0.5$ \\
\hline $\mathrm{TN}\left(\mathrm{mg} \mathrm{L}^{-1}\right)$ & $74.2 \pm 16.1$ & $60.7 \pm 13.8$ \\
\hline $\mathrm{TP}\left(\mathrm{mg} \mathrm{L}^{-1}\right)$ & $9.5 \pm 2.2$ & $6.9 \pm 1.3$ \\
\hline $\mathrm{Na}\left(\mathrm{mg} \mathrm{L}^{-1}\right)$ & $110.9 \pm 14.4$ & $118.7 \pm 11.4$ \\
\hline $\operatorname{Mg}\left(\mathrm{mg} \mathrm{L}^{-1}\right)^{\mathrm{b}}$ & 0.23 & 0.21 \\
\hline $\mathrm{Ca}\left(\mathrm{mg} \mathrm{L}^{-1}\right)$ & $19.5 \pm 2.4$ & $23.6 \pm 3.1$ \\
\hline $\mathrm{K}\left(\mathrm{mg} \mathrm{L}^{-1}\right)$ & $30.2 \pm 4.6$ & $28.4 \pm 5.3$ \\
\hline $\mathrm{Cl}\left(\mathrm{mg} \mathrm{L}^{-1}\right)$ & $83.7 \pm 31.3$ & $79.5 \pm 32.5$ \\
\hline $\mathrm{B}\left(\mathrm{mg} \mathrm{L}^{-1}\right)^{\mathrm{b}}$ & $<0.02$ & $<0.02$ \\
\hline $\mathrm{Cd}\left(\mathrm{mg} \mathrm{L}^{-1}\right)^{\mathrm{b}}$ & 0.03 & 0.02 \\
\hline $\mathrm{Cr}\left(\mathrm{mg} \mathrm{L}^{-1}\right)^{\mathrm{b}}$ & 1.38 & 0.1 \\
\hline $\mathrm{Co}\left(\mathrm{mg} \mathrm{L}^{-1}\right)^{\mathrm{b}}$ & 0.04 & 0.01 \\
\hline $\mathrm{Ni}\left(\mathrm{mg} \mathrm{L}^{-1}\right)^{\mathrm{b}}$ & 0.2 & 0.07 \\
\hline $\mathrm{Pb}\left(\mathrm{mg} \mathrm{L}^{-1}\right)^{\mathrm{b}}$ & 0.02 & 0.02 \\
\hline $\mathrm{Zn}\left(\mathrm{mg} \mathrm{L}^{-1}\right)^{\mathrm{b}}$ & 0.02 & $<0.01$ \\
\hline TC (NTU $100 \mathrm{~mL}^{-1}$ ) & $1.79 \times 10^{7} \pm 1120$ & $1.95 \times 10^{6} \pm 980$ \\
\hline FC (NTU $\left.100 \mathrm{~mL}^{-1}\right)$ & $3.78 \times 10^{6} \pm 458$ & $6.91 \times 10^{5} \pm 652$ \\
\hline E. coli (NTU $\left.100 \mathrm{~mL}^{-1}\right)$ & $5.02 \times 10^{6} \pm 879$ & $1.05 \times 10^{4} \pm 540$ \\
\hline $\mathrm{HE}$ (eggs $10 \mathrm{~L}^{-1}$ ) & $<10$ & $<10$ \\
\hline
\end{tabular}

a Average and confidence interval calculated for a confidence level of 95\% and the following number of samples: 42 (flow rate, temperature, $\mathrm{pH}, \mathrm{BOD}_{5}, \mathrm{COD}, \mathrm{TSS}$, $\mathrm{NH}_{4}-\mathrm{N}, \mathrm{NO}_{3}-\mathrm{N}, \mathrm{TN}, \mathrm{TP}, \mathrm{Na}, \mathrm{Ca}, \mathrm{K}$ and $\mathrm{Cl}$ ), 20 (EC and TC, FC), 10 (HE, E. coli).

b Only one measurement in the last sampling.

characteristic of the basin is the hydromineral aquifer that feeds the SPA of Cró (sulphurous water).

The agronomic use of reclaimed water in the studied area is not profitable since the agricultural land is scattered and has many family smallholdings. The agricultural lands are around $28 \%$ of the total land and are mainly located in granitic zones with medium altitude, provided with aquifer resources and with the following cultivations: dry cereals (winter season) and irrigated crops, corn, potatoes, beans and horticultural crops (spring and summer seasons).

\subsection{Reclaimed water monitoring}

A 21-month monitoring campaign (November 2007-November 2009) was set up in a subsurface horizontal flow CW (HSSF-CW) located at Vila Fernando village, which started 6 months after its start-up. The bed was colonized with Phragmites australis Trin. ex Steudel, filled with Filtralite MR 4-8 mm and had $23 \mathrm{~m} \times 18 \mathrm{~m}$ (length $\times$ width), a water depth of $0.5 \mathrm{~m}$ and was designed for flowrates from 26.5 to $49 \mathrm{~m}^{3} \mathrm{~d}^{-1}$, hydraulic loading rate (HLR) from 6 to $12 \mathrm{~cm} \mathrm{~d}^{-1}$, hydraulic retention time (HRT) from 5 to $9 \mathrm{~d}, \mathrm{BOD}_{5}$ from 200 to $400 \mathrm{mg} \mathrm{L}^{-1}$ and COD from 500 to $700 \mathrm{mg} \mathrm{L}^{-1}$.

The campaign included the daily measurement of flow-rate (entrance of the HSSF bed) and the collection of by-monthly samples (a single sampling approximately at the same day and hour) at the influent and effluent of the bed to determine $\mathrm{pH}$, temperature, biochemical oxygen demand $\left(\mathrm{BOD}_{5}\right)$, chemical oxygen demand (COD), total nitrogen (TN), ammonia nitrogen $\left(\mathrm{NH}_{4}-\mathrm{N}\right)$, nitrate nitrogen $\left(\mathrm{NO}_{3}-\mathrm{N}\right)$, total phosphorus (TP), total suspended solids (TSS), electric conductivity (EC), sodium (Na), calcium (Ca), potassium (K), chloride ( $\mathrm{Cl}$ ), Total Coliforms (TC), Faecal Coliforms (FC), Escherichia coli (E. coli) and Helminthes Eggs (HE). In the last sampling month, also measured was magnesium (Mg), boro (B), cadmium (Cd), chromium $(\mathrm{Cr})$, cooper $(\mathrm{Co})$, nickel $(\mathrm{Ni})$, lead $(\mathrm{Pb})$ 


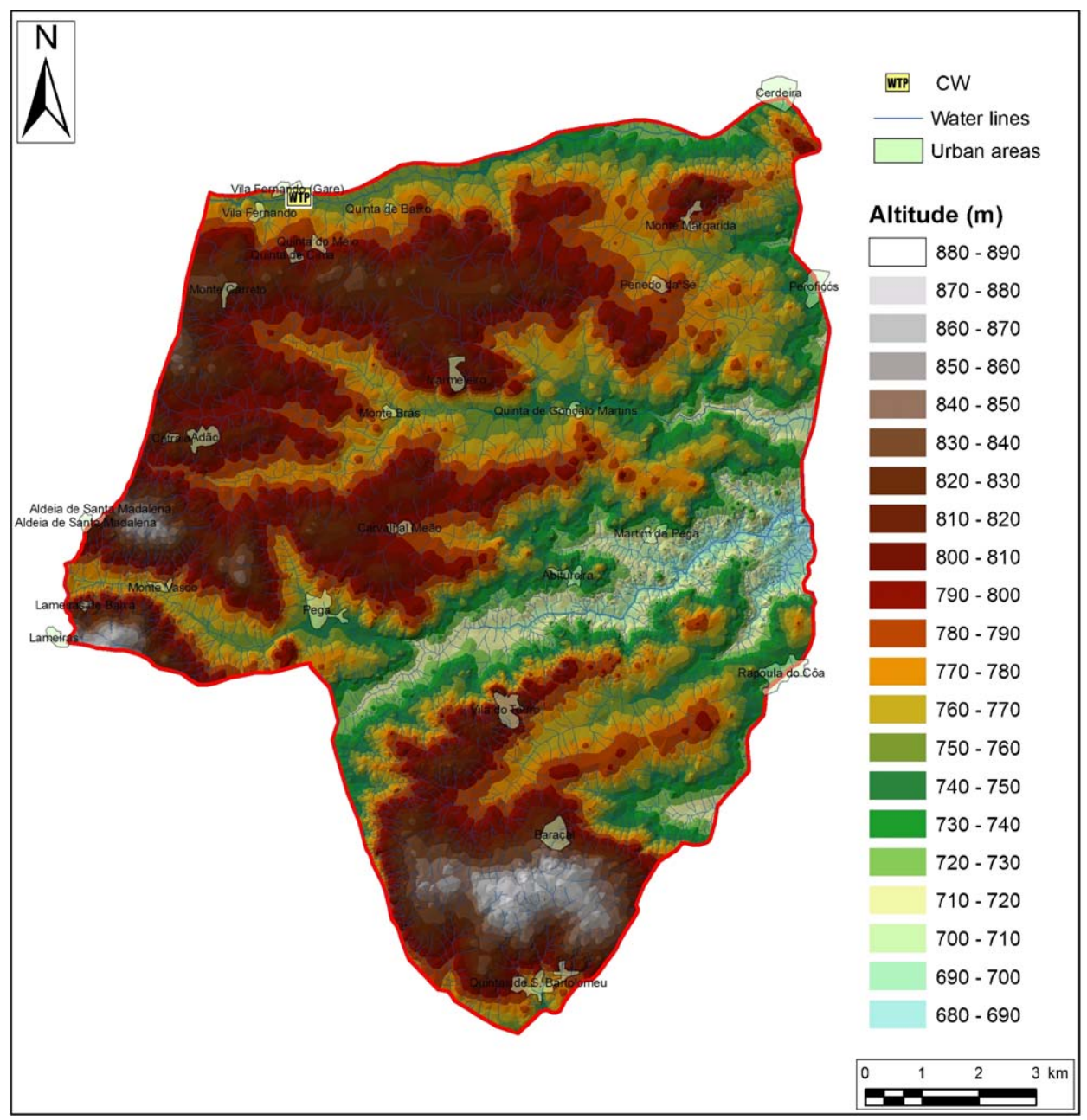

Fig. 2. Digital elevation model produced for the study area with a cell size of $10 \mathrm{~m} \times 10 \mathrm{~m}$.

and zinc ( $\mathrm{Zn})$. Mg was needed to estimate the Sodium Adsorption Ratio (SAR). B and heavy metals are phytotoxic parameters and need to be controlled.

The measurements of $\mathrm{pH}, \mathrm{EC}$ and temperature were carried out directly using a Tritilab TIM 900 (Radiometer, France). COD was determined with cuvette tests LCK $614\left(50-300 \mathrm{mg} \mathrm{L}^{-1}\right)$ following the standard DIN 38409-4 and a CADAS 50 spectrophotometer UV-Vis (HACH-LANGE, Germany). $\mathrm{BOD}_{5}$ and TSS were determined according to the 5210B, 2540D and 2540E standards, respectively, from the Standard Methods (APHA-AWWA-WEF, 1999).

$\mathrm{TN}, \mathrm{NH}_{4}-\mathrm{N}$ and TP were obtained using the cuvette tests LCK 138 (1-16 $\mathrm{mg} \mathrm{TNL}^{-1}$ ), LCK 238 (5-40 $\mathrm{mg} \mathrm{TN} \mathrm{L}^{-1}$ ), LCK 303 $\left(2-47 \mathrm{mg} \mathrm{NH}_{4}-\mathrm{NL}^{-1}\right)$ and LCK $350\left(2-20 \mathrm{mg} \mathrm{TP} \mathrm{L}^{-1}\right)$ following the method 2.6-dimethylphenol (TN, APHA-AWWA-WEF, 1999), the standard DIN 38406-E 5-1 $\left(\mathrm{NH}_{4}-\mathrm{N}\right)$ and the standard DIN 38405-D11-4 (TP), respectively, and the same spectrometer. For higher concentrations than the upper limits of the cuvette-tests the samples were previously diluted. $\mathrm{NO}_{3}-\mathrm{N}$ and $\mathrm{Cl}$ were analyzed using a Dionex-IX120 ion chromatography (Dionex Corp., USA) according to the standard ISO 10304$1: 2007$.

Heavy metals ( $\mathrm{Cd}, \mathrm{Cr}, \mathrm{Ni}, \mathrm{Pb}, \mathrm{Zn}$, and $\mathrm{Cu}$ ) were determined by atomic absorption spectroscopy with electrothermic atomizer (GBC-906, Australia) following the standard ISO 15586:2003. Na, $\mathrm{Ca}, \mathrm{K}$ and $\mathrm{Mg}$ were analyzed with the same equipment, but using air-acetylene flame method as described in the standards ISO
9964-1:1993 (Na and K) and ISO 7980:1986 (Ca and Mg). B was determined using a spectrophotometer UV-Vis (GBC-Cintra 40, Australia) following the Standard Methods 4500 B (APHA-AWWAWEF, 1999).

FC, TC and E. coli were analyzed following the standard ISO 9308-1:2000 and the Standard Methods 9221 B and 9221 E (APHA-AWWA-WEF, 1999). HE were determined through an optic microscopy (Ceti, Belgium) according to the modified Bailenger method (Ayres and Mara, 1996).

\subsection{Criteria for the identification of areas for aquifer recharge}

This step included the identification of the sites with potential for aquifer recharge, taking into account exclusion criteria (economic, environmental and technical constraints and the location of the SPA of Cró and its protected area), as well as the quality of the reclaimed water from the WWTP of Vila Fernando. The economic criteria included affordability and costs for adduction and pumping devices. The environmental criteria covered urban agglomerates, protected areas and water resources vulnerability. The technical criteria included soil and groundwater characteristics, aquifer depth, slope, land use, type of soil, soil texture, road accesses, infiltration velocity and distance between the CW and the infiltration sites. The criteria selected for the different variables were based on information published in international guidelines and studies (State of California, 1992; Pescod, 1992; Angelakis et al., 2003; EPA, 2006; Bixio and Wintgens, 2006; Asano et al., 2007; 


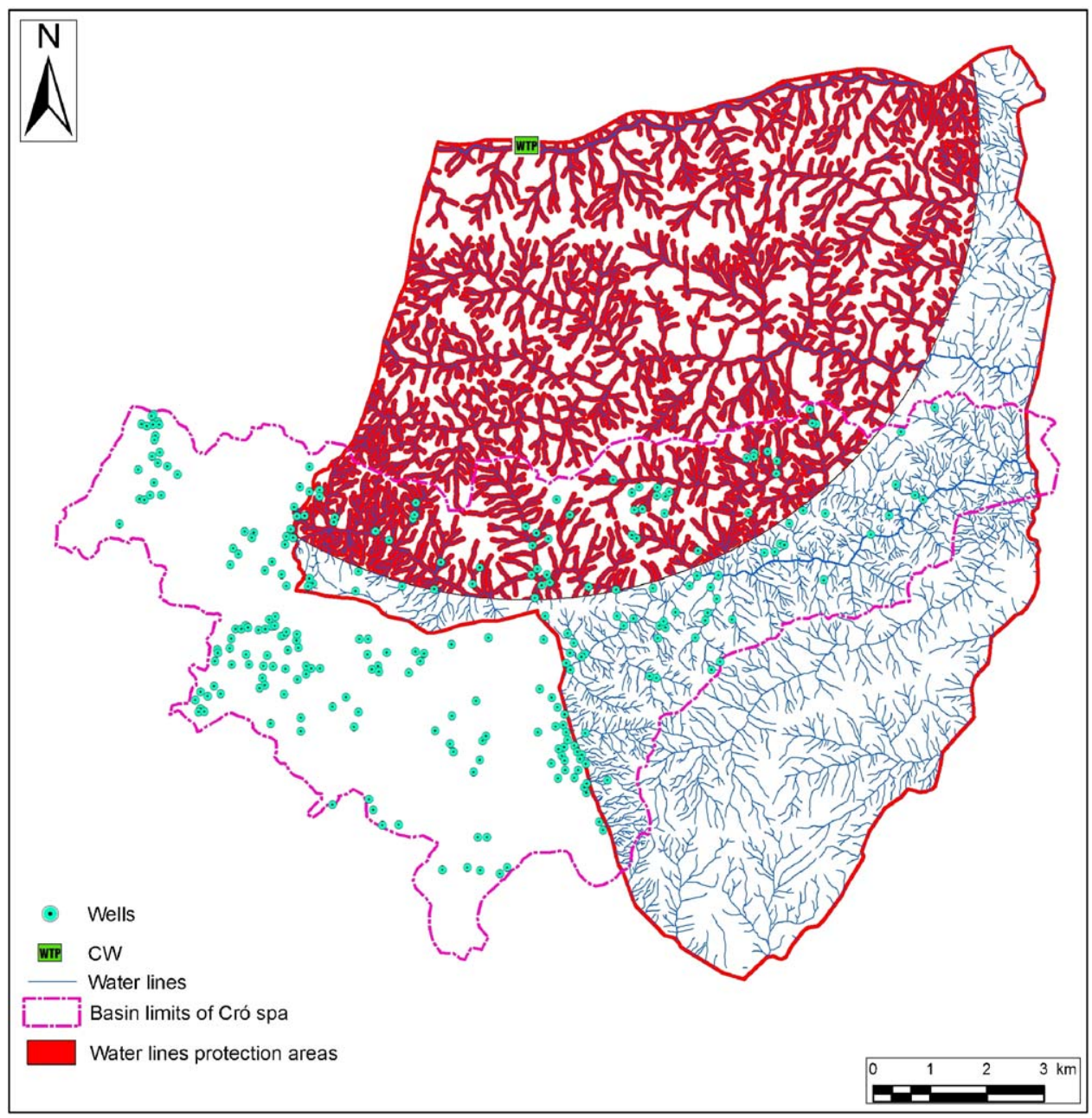

Fig. 3. Restriction map overlapping the economic criteria and the criteria for water supply sources.

Marecos do Monte and Albuquerque, 2010b), as well as on the experience of the authors in the selection of sites for biosolids reuse (Ribeiro et al., 2010).

\subsubsection{Economic criteria}

The economic criteria included water transfer costs from the WWTP to the infiltration sites (infiltration basins). As stated by EPA (2006), the main criteria should be the transport length from the WWTP to the potential application site, which should not exceed $8 \mathrm{~km}$, and the costs associated with pumping systems, which should not exceed $15 \mathrm{~m}$ in elevation. An area no more than $8 \mathrm{~km}$ away from the $\mathrm{CW}$ and with less than $15 \mathrm{~m}$ in elevation was defined as suitable for reclaimed water transport (from the WWTP of Vila Fernando as far as the limit of the protection area of the SPA of Cró).

\subsubsection{Environmental criteria}

The environmental criteria considered three variables: distance from water supply sources (reservoirs, streams and potable wells), urban agglomerations, and natural ecological reserves. A buffer area of $200 \mathrm{~m}$ around urban agglomerations and tourist areas was defined in order to avoid direct contact of the reclaimed water with the population and livestock, and a buffer area of $500 \mathrm{~m}$ around water reservoirs and of $100 \mathrm{~m}$ around wells and streams (both for water consumption or irrigation) was defined to avoid their contamination by reclaimed water infiltration. Areas classified as ecological reserve were also excluded.

\subsubsection{Technical criteria}

Six technical criteria variables were considered.

Land use: The Corine Land Cover map of the Portuguese Geographic Institute (produced in 2009) was used to evaluate the potential land use of the studied area.

Slope: Infiltration-percolation site should be feasibly constructed in slopes ranging from $0 \%$ to $12 \%$. Higher slopes increase runoff, soil erosion and therefore soil instability, which risks basin safety and increases refilling costs (EPA, 2006). Steeper areas and rocky areas would not be economically suitable, since they would require high costs of excavation.

Soil texture: Infiltration basins for SAT should be located in sandy loam, loamy sand and fine sand soils that are permeable enough to allow high infiltration rates, as well as to enhance the removal of trace organics, nutrients, heavy metals and pathogens (EPA, 2006; Asano et al., 2007). The unsaturated layer (vadose zone) should be higher than $5 \mathrm{~m}$ (Asano et al., 2007) to enhance SAT, and to avoid contamination of groundwater, and should not contain clay layers or other soils that could restrict the downward movement of water and form perched groundwater mounds. To minimize soil clogging and to ensure final reclaimed water polishing, the soil must have a clay fraction up to $10 \%$ (EPA, 2006). Therefore, soils with a clay fraction higher than $10 \%$ were not included.

Type of soil: Rocky soil should be avoided, whilst regosol and umbrisol are normally suitable for infiltration and SAT. Most of the residual load and pathogens in the reclaimed water are removed in 
the top $1 \mathrm{~m}$ of soil (Pescod, 1992). Any soils with a top depth lower than $1 \mathrm{~m}$ were not included.

Aquifer depth: Aquifers should be sufficiently deep and transmissive to prevent excessive rises of the groundwater table due to infiltration. The minimum static groundwater level accepted for reclaimed water infiltration is $5 \mathrm{~m}$ in order to have a sufficient vadose zone for a final purification (State of California, 1992; Pescod, 1992).

Roads: Road accesses to the infiltration sites allow quick maintenance and operation of the basins. Therefore, sites located at more than $50 \mathrm{~m}$ from roads were excluded as also adopted in a previous study (Ribeiro et al., 2010).

\subsection{Data analysis}

The elements with restrictions were located and georeferenced on the military maps in order to include the hydrographic network, water supply points, water irrigation systems, roads network, urban housing areas, isolated residential areas and land slopes. This work involved the confirmation of information in field visits and the development of the following tasks:

- conversion of some information from analogue to digital form;

- editing and processing of digital information;

- construction of a geographic model;

- construction of new thematic maps;
- spatial analysis of the thematic maps;

- structuring of alphanumeric and cartographic information.

A suitability map with areas for aquifer recharge was generated from ten thematic maps (digital elevation model, economic criteria buffer map, water supply sources buffer map, population buffer map, ecological reserve map, land use map, slope map, soil texture map, type of soil map and road buffer map) associated to the areas with a groundwater table higher than $5 \mathrm{~m}$ from the top soil. After this step, the areas with soil properties more suitable for reclaimed water infiltration were evaluated, since it is an important factor for aquifer recharge (EPA, 2006).

The analysis of the information was carried out using the software ArcGIS 9.1 (ESRI, USA) and the ArcCatalog and ArcMap applications, namely for the following main tasks:

- integration and management of spatial and non-spatial data (Raster or Vector);

- editing of both data and geographical entities;

- overlaying thematic information topics;

- spatial analysis (Spatial Analyst);

- design of slope maps (3D Analyst);

- definition of buffer zones on the border of geographical entities, using the buffer application;

- query of databases according to predefined criteria;

- georeferring of elements or entities;

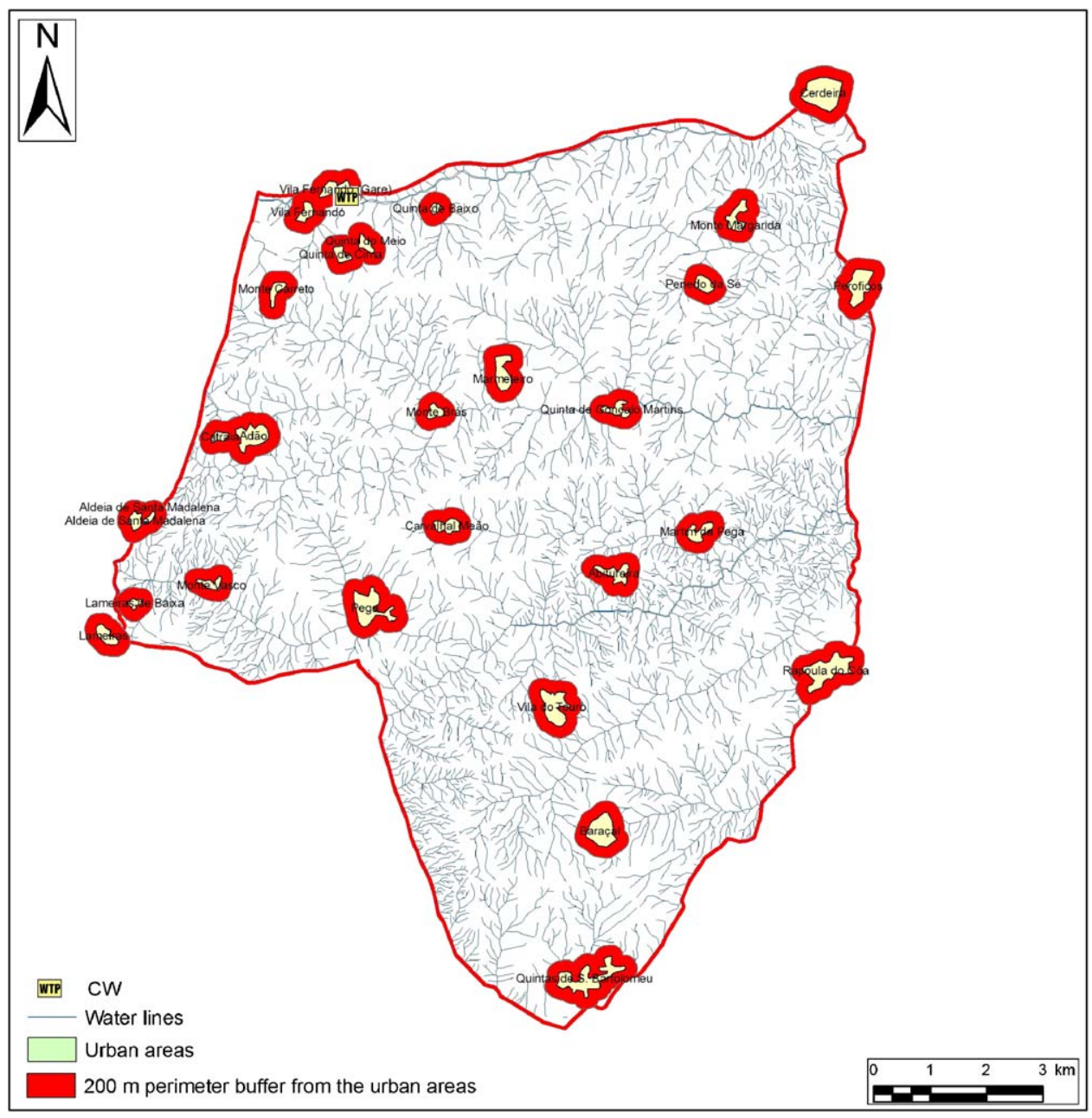

Fig. 4. Population agglomerates thematic map. 


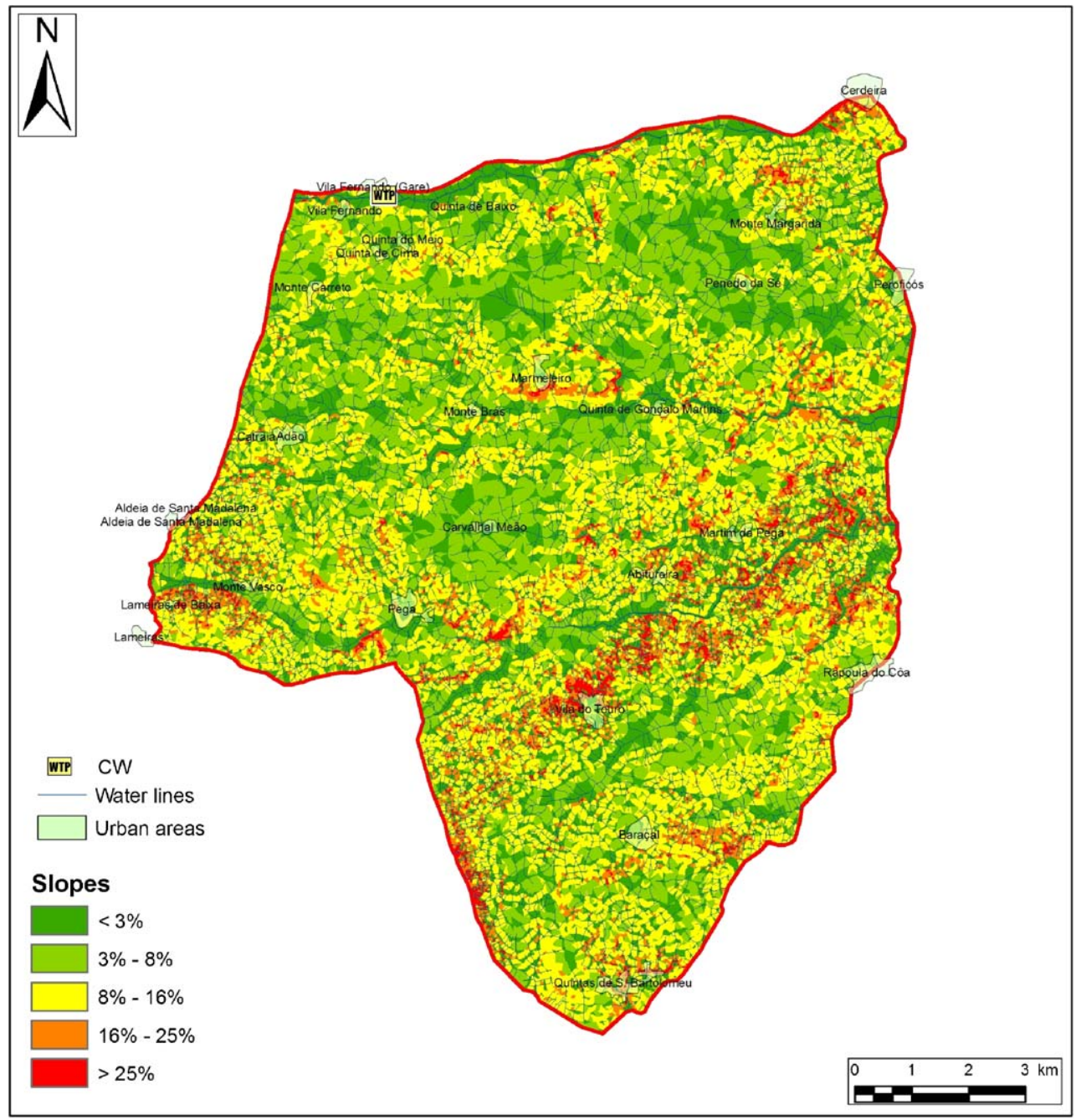

Fig. 5. Slope thematic map.

- geoprocessing of the information for mapping information in the selected study area;

- determination of the locations with higher suitability for reclaimed water infiltration using algebra of maps (Raster Calculator).

Spatial analysis was carried out through a representation of each selected variable by a thematic layer (thematic map). The thematic layers were developed from geographical data obtained from official sources, georeferenced data and data generated using satellite images and orthophotos. Each point (cells representing $10 \mathrm{~m} \times 10 \mathrm{~m}$ ) in each layer took a value ( 0 or 1 ) according to exclusion and inclusion criteria. Map algebra was used to make a Boolean operation between grid cells of different thematic maps in order to generate a final suitability map for the infiltration of reclaimed water.

\section{Results and discussion}

\subsection{Study area}

The area selected to carry out the study is located between the WWTP of Vila Fernando and the SPA of Cró intercepting its protected area as shown in Fig. 1, where altitudes range from $680 \mathrm{~m}$ to $880 \mathrm{~m}$. It was delimited from the digitalisation of parts of the Military Maps No. 192, 193, 194, 203, 204, 214, 215, 225 and 226 and the georeferenced limit of the protected area of the SPA of Cró, having been necessary to overlap cartographic elements. The total area assessed was 13,944 ha.

\subsection{Analysis of the reclaimed water}

The characteristics of the influent and effluent of the CW of Vila Fernando monitored during the 21 months are shown in Table 2.

The reclaimed water does not present salinity risks since the EC value are less than $0.7 \mathrm{dS} \mathrm{m}^{-1}$ (Asano et al., 2007). The SAR content was estimated through Eq. (1) (Asano et al., 2007; Marecos do Monte and Albuquerque, 2010a,b), considering the average concentrations of $\mathrm{Na}$ and $\mathrm{Ca}$ in the reclaimed water and the value of $\mathrm{Mg}$. The average value $(4.3 \pm 0.9)$ indicates that moderate to severe infiltration problems could occur unless a leaching fraction is carefully applied (Westcot and Ayers, 1985). This problem is mainly related to a relatively high average sodium concentration $\left(118.7 \mathrm{mg} \mathrm{L}^{-1}\right)$ and low calcium and magnesium concentrations $\left(23.6 \mathrm{mg} \mathrm{L}^{-1}\right.$ and $0.21 \mathrm{mg} \mathrm{L}^{-1}$, respectively).

$\mathrm{SAR}=\frac{\mathrm{Na}}{\sqrt{(\mathrm{Ca}+\mathrm{Mg}) / 2}}$

The concentration of phytotoxic ions $(\mathrm{B}, \mathrm{Cl})$ is under the thresholds for restriction on use $\left(<0.7 \mathrm{mg} \mathrm{L}^{-1}\right.$ and $<140 \mathrm{mg} \mathrm{L}^{-1}$, respectively) as suggested by Westcot and Ayers (1985). The heavy metal concentrations ( $\mathrm{Co}, \mathrm{Ni}, \mathrm{Pb}, \mathrm{Cr}$ and $\mathrm{Zn}$ ) are also below the 


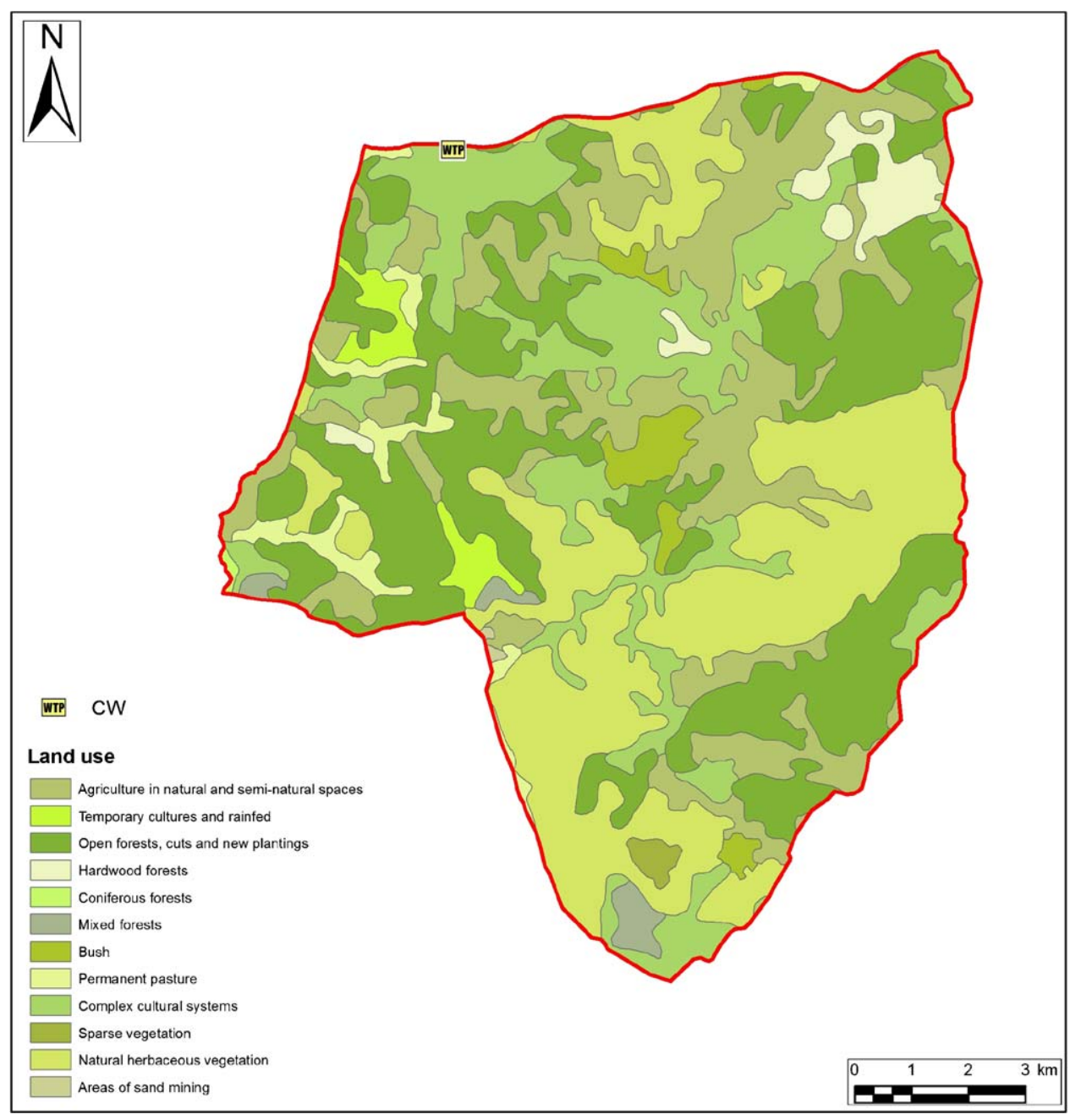

Fig. 6. Land use thematic map.

toxic levels ( $<0.05 \mathrm{mg} \mathrm{L}^{-1},<0.2 \mathrm{mg} \mathrm{L}^{-1},<5 \mathrm{mg} \mathrm{L}^{-1},<0.1 \mathrm{mg} \mathrm{L}^{-1}$ and $<2 \mathrm{mg} \mathrm{L}^{-1}$, respectively), but the concentration of $\mathrm{Cd}$ exceeds the toxic level limit $\left(0.010 \mathrm{mg} \mathrm{L}^{-1}\right)$ according to the same author.

Most of the soils of the studied region are classified as poor in terms of organic matter content and values below $1 \%$ were detected in 57 agricultural parcels (Ribeiro et al., 2010). Therefore, the organic content of the reclaimed water could contribute to improving soil organic carbon content (Chin-Ching et al., 2008) in low-fertility soils (Ahmed et al., 2009). Part of the organic matter will be incorporated into the soil and another part (namely the dissolved organic carbon) will be significantly oxidized by soil bacteria, typically from a range of $20-2 \mathrm{mg} \mathrm{L}^{-1}$ (Asano et al., 2007).

Nitrogen average concentration $\left(60.7 \mathrm{mg} \mathrm{L}^{-1}\right)$ is not very high and most of the ammonia will be oxidized to nitrite and nitrate due to nitrification in the upper layers of the soil. In the lower layers, nitrite and nitrate will be reduced to nitrogen gas due to denitrification. Therefore, the soil will act as SAT in the removal of ammonia, nitrite and nitrate. Phosphorus concentration is very low (6.9 $\left.\mathrm{mg} \mathrm{L}^{-1}\right)$ and will enter the soil in mineral forms, which tend to be retained by mineral colloids or to form phosphates (e.g. calcium phosphates, aluminium and iron) with low solubility.

The microbiological content is also high according to the health standards and regulations for wastewater reuse (WHO, 2006). The average removal is around $1 \log$ unit of TC, FC and E. coli. These results are in agreement with the ones obtained with HSSF-CW (removal up to $1.5 \log$ units; Arias et al., 2003; Torrens et al., 2009). HE were not detected $\left(<10\right.$ eggs $\left.10 \mathrm{~L}^{-1}\right)$.

Therefore, the parameters of concern in the reclaimed water from the CW of Vila Fernando are Cd and pathogens. If the infiltration basins for SAT are located in permeable sandy loam, loamy sand and fine sand soils with an unsaturated depth greater than $1 \mathrm{~m}$, the final concentrations of organics, nutrients, heavy metals and pathogens will be significantly reduced (Asano et al., 2007). Guessab et al. (1993) observed removal efficiencies up to $99.9 \%$ for FC and faecal streptococci in an infiltration-percolation system and a complete elimination of helminth and cestode eggs, for HLR up to $0.23 \mathrm{~m} \mathrm{~d}^{-1}$. Brissaud et al. (1991) observed removal of FC between 1.5 and 4 logs in sand columns for HLR of $0.5 \mathrm{~m} \mathrm{~d}^{-1}$.

Monitoring programs for reclaimed water infiltration must be set up using a conservative approach (i.e., with intensive monitoring of groundwater quality) in order to evaluate the effectiveness of the SAT.

\subsection{Suitable areas for reclaimed water infiltration}

The capture scale of the topographic data was 1:100,000 and a digital elevation model was produced for the study area with a cell size of $10 \mathrm{~m} \times 10 \mathrm{~m}$ (Fig. 2). For each thematic map the exclusion areas were coded as 0 and the inclusion areas as 1 . By overlapping 


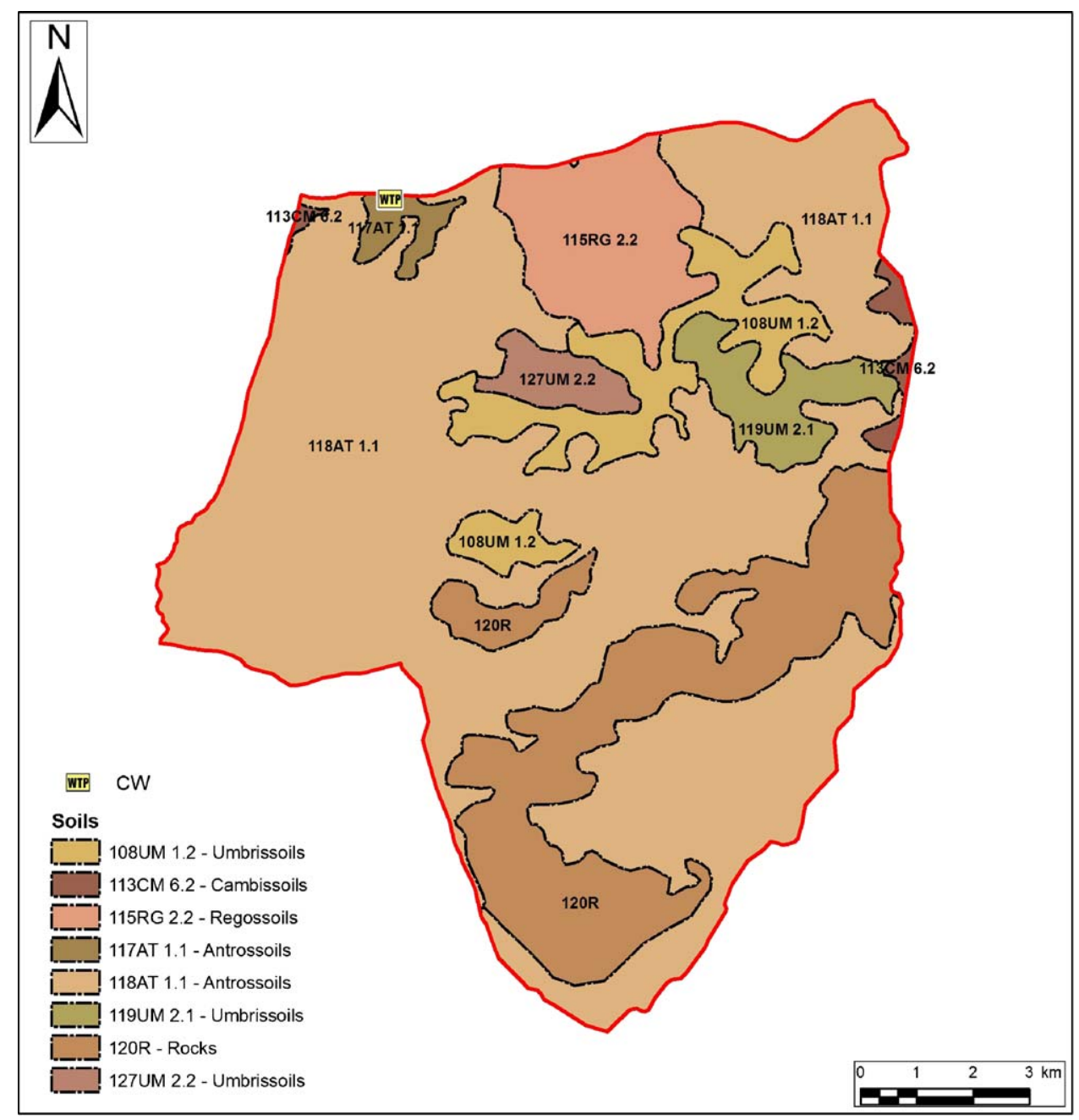

Fig. 7. Type of soil thematic map.

the economic criteria (a buffer area of $8 \mathrm{~km}$ radius around the WWTP of Vila Fernando, coded as 0 ) and the criteria for water supply sources (a buffer area of less than $100 \mathrm{~m}$ radius for streams and wells and less than $500 \mathrm{~m}$ radius for reservoirs, both coded as 0 ) it was possible to obtain the restriction map presented in Fig. 3. The population agglomerates thematic map was obtained by creating a buffer area of $200 \mathrm{~m}$ radius around villages, house agglomerations and isolated houses (coded as 0 ) as shown in Fig. 4. The urban agglomerations were dispersed because of the rural character of the area.

In order to define the slope thematic map the study area was firstly clipped and reclassified into two categories: one with values less than $12 \%$ (coded as 1 ) and another with higher values (coded as 0 ). A $10 \times 10$ majority filter was applied in order to smooth the distribution (Fig. 5). The raster layer obtained was converted to vector format. The studied area was irregular with medium hills with altitudes ranging from $680 \mathrm{~m}$ to $880 \mathrm{~m}$ in both sides of the Boi river bank. The total area with slopes less than $12 \%$ was 10,858 ha.

Land suitable for agriculture represents $28 \%$ of the total area and for forestry $85.2 \%$ (Fig. 6).

The soil texture and infiltration velocity thematic map was defined by clipping all polygons with a very low clay fraction (sandy loam, loamy sand, fine sand), which were assembled together and coded as 1 . The remaining polygons were coded as 0 . The sites located at more than $50 \mathrm{~m}$ from roads were coded as 0 .
The predominant soils in the studied area are anthrosol (63.8\%), rock (17\%), umbrisol (12.4\%) and regosol (6.8\%) as seen in Fig. 7. Taking into account the variables of soil texture, infiltration velocity and type of soil, the most suitable soil is regosol because it has a plaggic horizon with a thickness greater than $1 \mathrm{~m}$ and can ensure the soil treatment.

A GIS in raster format was used to create the suitability map for the location of infiltration areas for aquifer recharge and the results were processed according to the algebra of maps (maps overlapping for the different variables, operated in $10 \mathrm{~m} \times 10 \mathrm{~m}$ cells sized). The suitability map was produced from the ten thematic maps (digital elevation model, economic criteria buffer map, water supply sources buffer map, population buffer map, ecological reserve map, land use map, slope map, soil texture map, type of soil map and road buffer map) and the areas with a groundwater table higher than $5 \mathrm{~m}$.

The computation procedure involved the overlap between the restricted areas of each of the ten thematic maps and the suitable areas for reclaimed water infiltration through algebraic operations of maps as presented in Eq. (2).

$\left(M_{i j}^{k}\right)_{m n} \times W=\sum_{k=1}^{t m}\left(\left(\begin{array}{cccc}M_{11}^{k} & M_{12}^{k} & \cdots & M_{1 n}^{k} \\ M_{21}^{k} & M_{22}^{k} & \cdots & M_{2 n}^{k} \\ \cdots & \cdots & \cdots & \cdots \\ M_{m 1}^{k} & M_{m 2}^{k} & \cdots & M_{m n}^{k}\end{array}\right) \times W^{k}\right)$ 


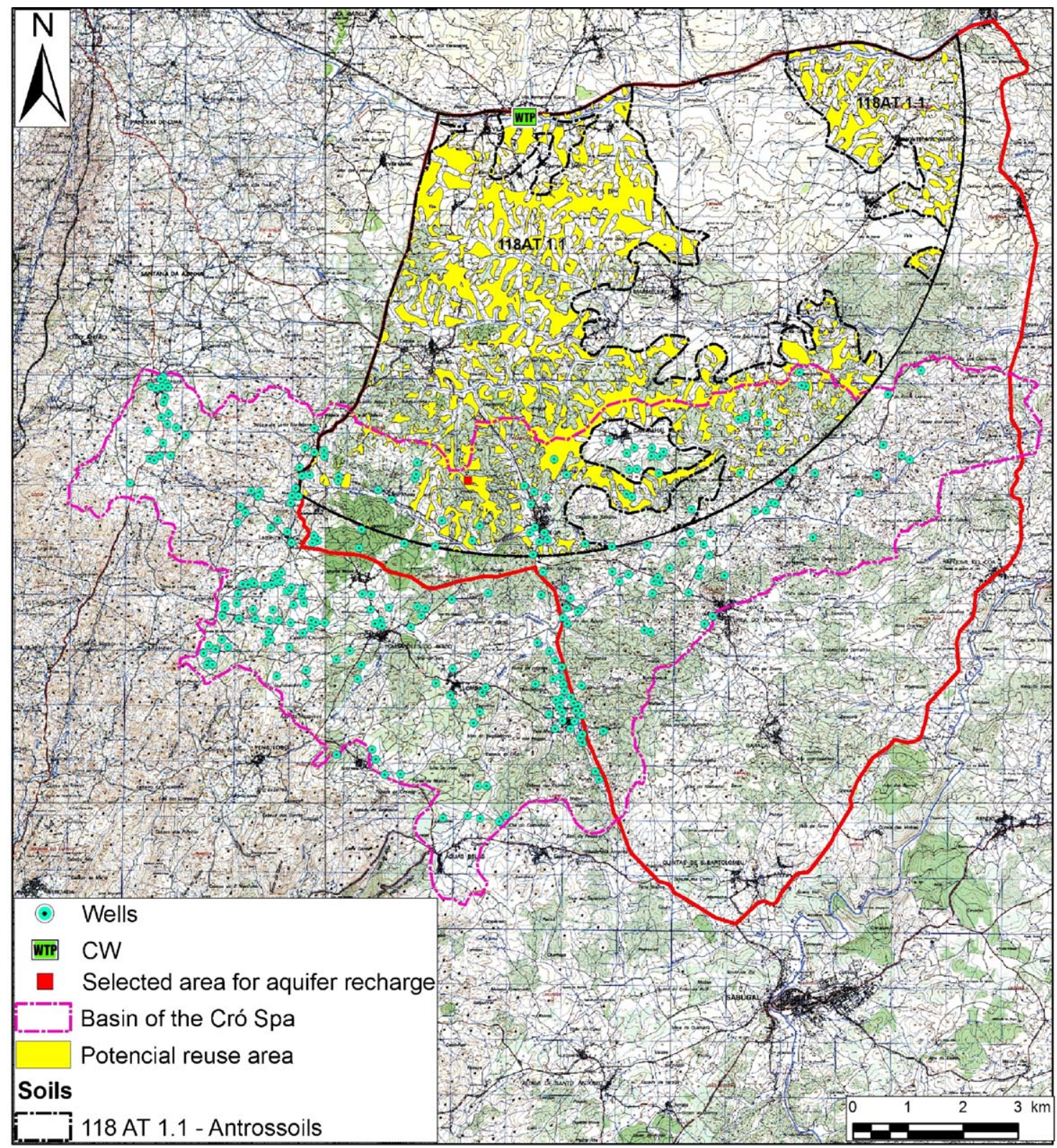

Fig. 8. Final suitability map for reclaimed water infiltration.

where $M_{i j}^{k}$ is the vector of cell values from each thematic map which is in line $i$ in row $j, m$ and $n$ are the dimensions of the thematic grid map, $k$ is the thematic map, $t m$ is the number of thematic maps and $W$ is the vector of values associated to each cell ( 0 for exclusion areas; 1 for inclusion areas).

The value of each cell of the final suitability map resulted from the Boolean operation between the value ( 0 or 1$)$ stored in each cell of each thematic map. Eq. (3) was therefore inserted in the Raster Calculator function to calculate the final suitability map, which is presented in Fig. 8.

$\left(S_{i j}\right)_{m n}=\left(\begin{array}{cccc}S_{11} & S_{12} & \cdots & S_{1 n} \\ S_{21} & S_{22} & \cdots & S_{2 n} \\ \cdots & \cdots & \cdots & \cdots \\ S_{m 1} & S_{m 2} & \cdots & S_{m n}\end{array}\right)$

where $\left(S_{i j}\right)$ is the vector of cell values for the suitability map that is in line $i$ in row $j, m$ and $n$ are the dimensions of the suitability grid map.
The final potential area for infiltration of reclaimed water is 1607 ha (12\%) of the total studied area (13,944 ha). The most restrictive variable was the availability of water supply sources (Table 3) due to the presence of hundreds of water lines in the hydrographic basin of the studied area.

\subsection{Final area for infiltration basins}

Groundwater tables should be at least $1 \mathrm{~m}$ below the bottom of the infiltration basins during flooding periods in order to allow an unsaturated area suitable for SAT and to avoid groundwater contamination. Most of the removal of residual pollutants and pathogens in a SAT system occurs in the top $1 \mathrm{~m}$ of soil (Pescod, 1992). The water depth of the aquifer in the selected area for infiltration (Fig. 8-yellow areas) ranges from $10 \mathrm{~m}$ to $50 \mathrm{~m}$ (Cavaleiro, 2002). Therefore, a minimum of $5 \mathrm{~m}$ depth for SAT is ensured in all the selected anthrosol soils to improve the quality of the reclaimed water from the CW of Vila Fernando. 
Table 3

Suitable area for different parameters.

\begin{tabular}{lr}
\hline Parameters & \multicolumn{1}{c}{ Area (ha) } \\
\hline Studied area & 13,944 \\
Area without population agglomerates & $12,445(89 \%)$ \\
Economic restriction area & $7805(56 \%)$ \\
Area with slopes $<12 \%$ & $10,852(78 \%)$ \\
Area occupied by for anthrosol soils & $8862(64 \%)$ \\
Area without restricted water sources & $5345(38 \%)$ \\
Area suitable for infiltration & $1607(12 \%)$ \\
\hline
\end{tabular}

The final area for infiltration basins was calculated according to the method presented in Bouwer (2002). The HLR to be applied to the infiltration basins should take into account the time necessary for regular drying and periodic cleaning and the soil clogging risk. Soil clogging may cause the decrease of the infiltration rates from $1 \mathrm{~m} \mathrm{~d}^{-1}$ to $0.5 \mathrm{~m} \mathrm{~d}^{-1}$ after 2 weeks of flooding. Assuming that a drying period of 2 weeks is necessary to clean the basin and to restore the infiltration rate up to $1 \mathrm{md}^{-1}$, the basins should be sized for an average HLR of $0.75 \mathrm{~m} \mathrm{~d}^{-1}$ during the flooding period and zero infiltration during the drying/cleaning period. Therefore, the longterm average HLR throughout the flooding/drying cycle would be $0.375 \mathrm{~m} \mathrm{~d}^{-1}$ (approximately $137 \mathrm{~m}$ year $^{-1}$ ).

In order to allow a flexible operation of the basins without compromising the recharge, more than one basin should be sized to work in parallel. Flooding schedules typically vary from $8 \mathrm{~h}$ dry-16 h flooding to 2 weeks dry-2 weeks flooding (Pescod, 1992). In order to allow a proper SAT associated with the infiltration basins, these structures should be sized to work on alternating cycles (some are flooded; some are dried). Therefore, taking into account the maximum flow-rate produced at the CW of Vila Fernando $\left(240 \mathrm{~m}^{3} \mathrm{~d}^{-1}\right)$ and an annual average infiltration rate of $0.375 \mathrm{~m} \mathrm{~d}^{-1}, 4$ basins with $320 \mathrm{~m}^{2}$ each would be necessary to ensure the infiltration of all the annual reclaimed water produced at the WWTP of Vila Fernando and the proper aquifer recharge.

As a final remark, taking into account the number of small wastewater treatment facilities in the study area (10 HSSF-CW), the annual volume of reclaimed water that could be used for aquifer recharge would increase up to $133,000 \mathrm{~m}^{3}$. Therefore, the infiltration of that volume of reclaimed water would provide an important source of water for groundwater in an area of water scarcity and, at the same time, could contribute to minimize negative environmental impacts associated with the discharge of residuals into water streams.

\section{Conclusions}

Sites for aquifer recharge with reclaimed water from HSSF-CW were studied in the northwest area of the Beira Interior region (Portugal), using GIS tools. Technical, environmental and economic criteria were set up, which allowed building ten thematic maps. The applications of multi-criteria analysis allow obtaining a final suitability map with proper areas (1607 ha) for reclaimed water infiltration. Taking into account the type of soil, the average groundwater level and the requirements for a proper SAT to remove residuals and pathogens of the reclaimed water, four basins with a total of $1280 \mathrm{~m}^{2}$, located in anthrosol soils, would be enough to allow the infiltration of all the reclaimed water produced at the WWTP of Vila Fernando. With this work, a new use is indicated for the reclaimed water from CW systems in the rural areas of the Beira Interior region, reducing the discharge of residuals into water streams and obtaining a new water source for aquifer recharge.

\section{Acknowledgements}

The authors wish to thank the Portuguese Foundation for Science and Technology, which funded the work through the project PTDC/AMB/73081/2006 as well as the support provided by Jose Riscado during the study.

\section{References}

Ahmed C, Rouina B, Sensoy S, Boukhriss M. Saline water irrigation effects on fruit development, quality, and phenolic composition of virgin olive oils, vv. Chemlali. Journal of Agricultural and Food Chemistry 2009;57:2803-11.

Angelakis A, Bontoux L, Lazarova V. Main challenges for water recycling and reuse in EU countries. Water Supply 2003;3(4):59-68.

Angelakis A, Marecos do Monte H, Bontoux L, Asano T. The status of wastewater reuse practise in the Mediterranean basin: need for guidelines. Water Resources 1999;33(10):2201-17.

APHA-AWWA-WEF. Standard methods for the examination of water and wastewater. 20th ed. Washington, DC, USA: American Public Health Association/American Water Works Association/Water Environment Federation; 1999.

Arias C, Cabello A, Brix H, Johansen N. Removal of indicator bacteria from municipal wastewater in an experimental two-stage vertical flow constructed wetland system. Water Science and Technology 2003;48(5):35-41.

Asano T, Burton F, Leverenz H, Tsuchihashi R, Tchobanoglous G. Water reuse. 1st ed. New York, USA: McGrawHill; 2007.

Ayres R, Mara D. Analysis of wastewater for use in agriculture. A laboratory manual of parasitological and bacteriological techniques. Geneva, Switzerland: World Health Organization; 1996.

Bixio D, Wintgens T. Water reuse system management. Manual AQUAREC. Brussels, Belgium: Directorate-General for Research, European Commission; 2006.

Bouwer $\mathrm{H}$. Artificial recharge of groundwater: systems, design, and management. In: Mays LW, editor. Hydraulic design handbook. New York, USA: McGraw-Hill; 1999. p. 24.1-.44.

Bouwer $\mathrm{H}$. Artificial recharge of groundwater: hydrogeology and engineering. Hydrogeology Journal 2002;10:121-42.

Brissaud F, Restrepo M, Soulié M. Infiltration for reclaiming stabilization pond effluents. Water Science and Technology 1991;24:185-93.

Cavaleiro V. The protection perimeter of the SPA of Cró. Technical report. Portugal: UBI; 2002, 85 pp. (in Portuguese).

Chin-Ching L, Arun A, Rekha P, Chiu-Chung Y. Application of wastewater from paper and food seasoning industries with green manure to increase soil organic carbon: a laboratory study. Bioresource Technology 2008;99: 6190-7.

EPA. Process design manual for land treatment of municipal wastewater. Cincinnati, USA: US Environmental Protection Agency, Center for Environmental Research Information; 2006.

Gemitzia A, Tsihrintzis V, Christouc O, Petalas C. Use of GIS in siting stabilization pond facilities for domestic wastewater treatment. Journal of Environmental Management 2007;82:155-66.

Ghermandi A, Bixio D, Thoeye C. The role of free water surface constructed wetlands as polishing step in municipal wastewater reclamation and reuse. Science the Total Environment 2005;380(1-3):247-58.

Guessab M, Bize J, Schwartzbrod J, Maul A, Morlot M, Nivault N, et al. Wastewater treatment by infiltration-percolation on sand: results in Ben-Sergao, Morocco. Water Science and Technology 1993;27(9):91-5.

Kanarek A, Michail M. Groundwater recharge with municipal effluent: Dan region reclamation project, Israel. Water Science and Technology 1996;34(10): 227-33.

Marecos do Monte H, Albuquerque A. Analysis of constructed wetland performance for irrigation reuse. Water Science and Technology 2010a;61(7):1699-705.

Marecos do Monte H, Albuquerque A. Wastewater reuse. Technical Guide No. 14 Lisbon, Portugal: ERSAR; 2010b, 319 pp. (in Portuguese).

Marecos do Monte H. Water reuse in Europe. Official Publication of the European Water Association (EWA). Hennef, Germany: EWA; 2007.

Mitchell G. Mapping hazard from urban non-point pollution: a screening model to support sustainable urban drainage planning. Journal of Environmental Management 2005;74:1-9.

Pescod M. Wastewater treatment and use in agriculture. FAO Irrigation and Drainage Paper 47. Rome, Italy: FAO; 1992.

Ribeiro P, Albuquerque A, Quinta-Nova L, Cavaleiro V. Recycling of pulp mill sludge to improve soil fertility using GIS tools. Resources, Conservation \& Recycling 2010;54:1303-11.

State of California. Proposed guidelines for groundwater recharge with recycled municipal wastewater, and background information on proposed guidelines for groundwater recharge with recycled municipal wastewater. Interagency water reclamation coordinating committee and the Groundwater recharge committee. Sacramento, USA: State of California; 1992.

Torrens A, Molle M, Boutin C, Salgot M. Removal of bacterial and viral indicators in vertical flow constructed wetlands and intermittent sand filters. Desalination 2009;246(1-3):168-78.

Tsuchihashi R, Sakaji R, Asano T. Health aspects of groundwater recharge with reclaimed water. In: 4th international symposium on artificial recharge of groundwater; 2002. 
UNESCO. Water in a changing world (WWDR-3). 3rd United Nations World Water Development Report. London, United Kingdom: UNESCO; 2009, $320 \mathrm{pp}$.

Vymazal J, Kropfelova L. Wastewater treatment in constructed wetlands with horizontal sub-surface flow. Series of Env. Poll. 14. Heidelberg, Germany: Springer; 2008, 566 pp.
Westcot D, Ayers R. Irrigation water quality criteria. In: Pettygrove G, Asano T, editors. In Irrigation with reclaimed municipal wastewater-a guidance manual. Chelsea, USA: Lewis Publishers; 1985.

WHO. Guidelines for the safe use of wastewater, excreta and greywater. Volume 2: wastewater use in agriculture. Geneva, Switzerland: World Health Organization; 2006. 